\title{
Structure-Activity Relationship of Piplartine and Synthetic Analogues against Schistosoma mansoni and Cytotoxicity to Mammalian Cells
}

Yuri Campelo ${ }^{1,2,3}$, Alicia Ombredane ${ }^{4}$, Andreanne G. Vasconcelos ${ }^{5}$, Lucas Albuquerque ${ }^{6}$, Daniel C. Moreira ${ }^{5}$ (D), Alexandra Plácido ${ }^{7}$, Jefferson Rocha ${ }^{2}$, Harold Hilarion Fokoue ${ }^{8}$, Lydia Yamaguchi ${ }^{9}$, Ana Mafud ${ }^{10}\left(10\right.$, Yvonne P. Mascarenhas ${ }^{10}$, Cristina Delerue-Matos ${ }^{7}$, Tatiana Borges ${ }^{6}$, Graziella A. Joanitti ${ }^{4}$, Daniel D. R. Arcanjo ${ }^{11}$ (iD), Massuo J. Kato ${ }^{9}$, Selma A. S. Kuckelhaus ${ }^{5}$, Marcos P. N. Silva ${ }^{12}$, Josué de Moraes ${ }^{12}$ and José Roberto S. A. Leite ${ }^{1,5, * \text { (iD }}$

1 Núcleo de Pesquisa em Biodiversidade e Biotecnologia, Biotec, Universidade Federal do Piauí, UFPI, Parnaíba-PI, 64202-020 Brazil; yd.dias@hotmail.com

2 Programa de Pós-Graduação em Biotecnologia, RENORBIO, Ponto focal Universidade Federal do Piauí, UFPI, Teresina, PI, 64049-550, Brazil; jeffersonbiotec@gmail.com

3 Instituto de Educação Superior do Vale do Parnaíba, FAHESP/IESVAP, Parnaíba-PI, 64212-790, Brazil

4 Laboratório de Nanobiotecnologia, Instituto de Biologia, Campus Darcy Ribeiro, Universidade de Brasília, UnB, Brasília-DF 70910-900, Brazil; aliciaombredane@gmail.com (A.O.); bygra1@gmail.com (G.A.J.)

5 Área de Morfologia, Faculdade de Medicina, Universidade de Brasília, UnB, Brasília-DF 70910-900, Brazil; andreannegv@gmail.com (A.G.V.); danielcarmor@gmail.com (D.C.M.); selmask@gmail.com (S.A.S.K.)

6 Laboratorio de Imunologia, Faculdade de Medicina, Universidade de Brasília, UnB, Brasília-DF 70910-900, Brazil; lucasfriaca@hotmail.com (L.A.); tatianakarlab@gmail.com (T.B.)

7 LAQV/REQUIMTE, GRAQ, Instituto Superior de Engenha do Porto, ISEP, Porto 4200-072, Portugal; alexandra.placido@gmail.com (A.P.); cmm@isep.ipp.pt (C.D.-M.)

8 Laboratório de Avaliação e Síntese de Substâncias Bioativas, Universidade Federal do Rio de Janeiro, CCS, Cidade Universitária, Rio de Janeiro-RJ 21941-902, Brasil; hfokoue@gmail.com

9 Instituto de Química, Universidade de São Paulo, São Paulo-SP 01005-010, Brazil; lydyama@gmail.com (L.Y.); majokato@iq.usp.br (M.J.K.)

10 Instituto de Física de São Carlos, Universidade de São Paulo-SP 01005-010, Brazil; carolmafud@gmail.com (A.M.); yvonne@ifsc.usp.br (Y.P.M.)

11 Núcleo de Pesquisas em Plantas Medicinais, NPPM, Universidade Federal do Piauí, UFPI, Parnaíba-PI 64202-020, Brazil; daniel.arcanjo@ufpi.edu.br

12 Núcleo de Pesquisa em Doenças Negligenciadas, Universidade de Guarulhos, Guarulhos-SP 07023-070, Brazil; marcos.p.bio@gmail.com (M.P.N.S.); josuem@usp.br (J.d.M.)

* Correspondence: jrsaleite@gmail.com or jrsaleite@pq.cnpq.br; Tel.: +55-61-3107-1891

Received: 30 December 2017; Accepted: 27 February 2018; Published: 19 June 2018

\begin{abstract}
Schistosomiasis, caused by helminth flatworms of the genus Schistosoma, is an infectious disease mainly associated with poverty that affects millions of people worldwide. Since treatment for this disease relies only on the use of praziquantel, there is an urgent need to identify new antischistosomal drugs. Piplartine is an amide alkaloid found in several Piper species (Piperaceae) that exhibits antischistosomal properties. The aim of this study was to evaluate the structure-function relationship between piplartine and its five synthetic analogues (19A, 1G, 1M, 14B and 6B) against Schistosoma mansoni adult worms, as well as its cytotoxicity to mammalian cells using murine fibroblast (NIH-3T3) and BALB/cN macrophage (J774A.1) cell lines. In addition, density functional theory calculations and in silico analysis were used to predict physicochemical and toxicity parameters. Bioassays revealed that piplartine is active against $S$. mansoni at low concentrations $(5-10 \mu \mathrm{M})$, but its analogues did not. In contrast, based on 3-(4,5-dimethylthiazol-2-yl)-2,5-diphenyltetrazolium bromide (MTT) and flow cytometry assays, piplartine exhibited toxicity in mammalian cells at $785 \mu \mathrm{M}$, while its analogues $19 \mathrm{~A}$ and $6 \mathrm{~B}$ did not reduce cell viability at the same concentrations.
\end{abstract}


This study demonstrated that piplartine analogues showed less activity against $S$. mansoni but presented lower toxicity than piplartine.

Keywords: piplartine; analogues; Schistosoma mansoni; cytotoxicity

\section{Introduction}

Schistosomiasis, caused by helminth flatworms of the genus Schistosoma, is a chronic and often painful disease mainly associated with poverty that affects more than 200 million people worldwide, resulting in major economic and personal impacts from the years of healthy life lost to morbidity [1]. Recent global burden of disease estimates indicate that approximately 10,000 schistosomiasis-related deaths occur each year [2]. Moreover, the current estimate of yearly disability adjusted life-years (DALYs) for schistosomiasis is 3.4 million [3]. Three species (Schistosoma mansoni, Schistosoma haematobium and Schistosoma japonicum) account for the majority of human infections. The major aetiological agent of human schistosomiasis is S. mansoni and intestinal schistosomiasis caused by this species is present in Africa, the Middle East, the Caribbean, and South America [4].

Human treatment with praziquantel is playing a central role in the control and prevention of schistosomiasis, being the only effective drug currently available [5]. However, praziquantel does not prevent re-infection and its continued extensive use may result in the future emergence of drug-resistant parasites. Having a single drug to treat a disease that affects millions of people is a real concern and, consequently, it is imperative to develop new effective antischistosomal drugs [6].

The use of natural products has a long tradition in medicine, and they have proven to be an important source of lead compounds in the development of new drugs. In order to provide new compounds for use in drug development to control schistosomiasis, the search for anthelmintic compounds, mainly from natural sources, has intensified in recent years [7-11]. Indeed, as reviewed elsewhere, natural compounds have been recognized as promising candidates for antischistosomal drugs [12].

In the north-eastern region of Brazil, several plants with active metabolites have been discovered, among them is the Piperaceae family, which includes several compounds with antimicrobial activities [13]. Piplartine (3,4,5-trimethoxycinnamoyl- $N$-dihydropyridin-2-one), also known as piperlongumine were described in several species of Piper genus, and anti-inflammatory, antitumor, antifungal, and antiparasitic effects were reported (for review see [14]). Our group previously demonstrated that piplartine at $10 \mu \mathrm{M}$ possesses in vitro schistosomicidal activity against $S$. mansoni schistosomula and adult worms $[15,16]$. We also showed that piplartine caused morphological alterations in the tegument of parasites in a concentration-dependent manner. The antischistosomal effect of piplartine in association with other molecules (e.g., praziquantel) had also been described [17,18].

The activity of a molecule is characterised not only by its biological activity against microorganisms, but also by its toxicity in various mammalian cells. Toxicity studies are, therefore, performed prior to the administration of a molecule to humans. In order to establish a relationship between the chemical structure of piplartine and its biological effects, in this study new analogues of piplartine were synthesised and evaluated against adult $S$. mansoni ex vivo. The cytotoxicity of compounds was also evaluated on murine fibroblast (NIH-3T3) and BALB/cN macrophage (J774A.1) cell lines. Additionally, we also performed theoretical calculations and ultraviolet-visible absorption spectra to characterize the obtained compounds. Furthermore, physicochemical and toxicological parameters of piplartine and its derivatives were obtained by a computer-aided prediction. 


\section{Results}

\subsection{Theoretical Calculations and Ultraviolet-Visible Absorption Spectra}

The electron density data for the tested molecules are shown in Figure 1, and indicate that piplartine had the highest dipole moment (5.47). Regions coloured red tended to have a more negative charge, being polar, while those in blue were more positive. Figure 2 represents the ultraviolet-visible (UV-Vis) light absorption spectrum of piplartine and its analogues, showing maximum absorbance from 280 to $400 \mathrm{~nm}$, with dislocation at the bands of the analogues in relation to the original molecule.

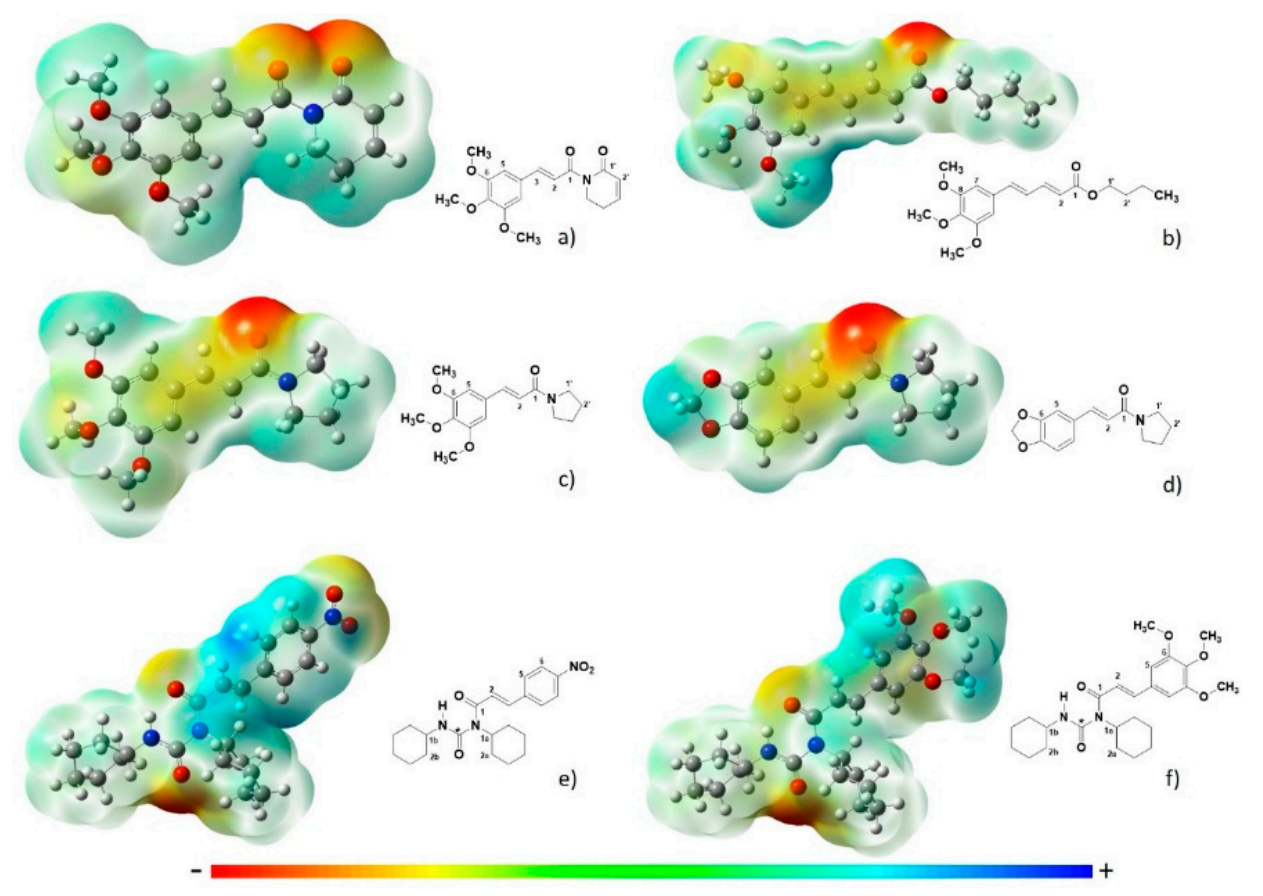

Figure 1. Electron density: (a) piplartine; (b) 19A; (c) 1G; (d) 14B; (e) 6B and (f) 1M. The colours represent negative (red) and positive (blue). The dipole moments of all compounds in debye values are as follows: piplartine: 5.4728337; 1G: 1.9658996; 1M: 4.4568136; 6B: 4.0062111; 14B: 3.9403826; 19A: 3.7385640.

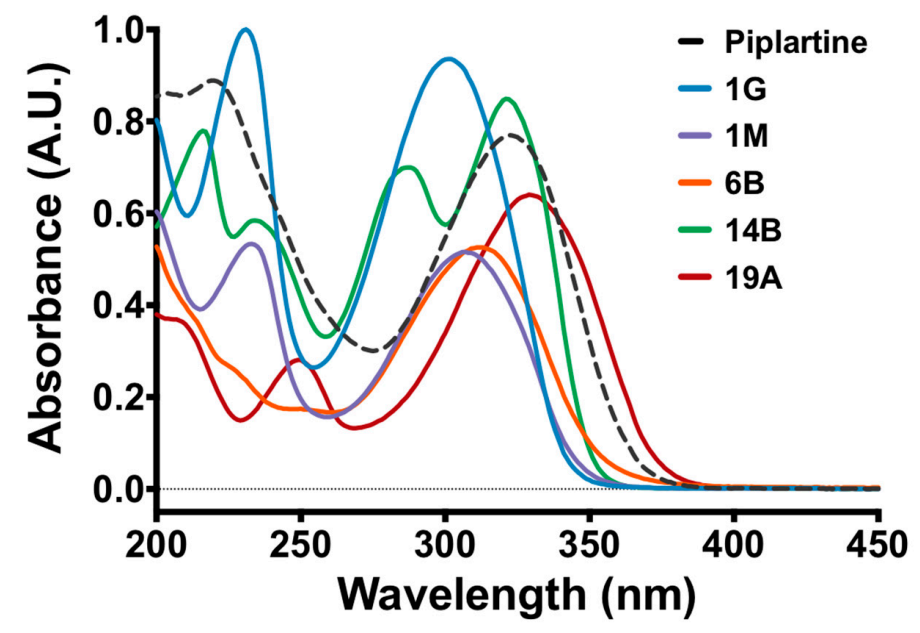

Figure 2. Ultraviolet and visible light absorption spectra of piplartine and its analogues in arbitrary units (A.U.). 


\subsection{In Silico Studies Information}

To investigate the differences between piplartine and its analogues, a structural and physicochemical analysis was performed to calculate the van der Waals surface area (vdW), molecular electrostatic potential (MEP) surface, molecular lipophilicity potential (MLP) and polar surface area (PSA), $\log _{P}$ values, predicted solubility, and molecular weight of the compounds, using the ChemAxon method. The results are shown in Table 1. Despite significant differences in surface area, the most significant difference between the compounds was in the topological polarised surface area (TPSA). TPSA of a molecule was defined as the surface sum over all polar atoms and is based simply on the summation of polar fragments representing tabulated surface contributions, i.e., bonding patterns of a molecule [19]. The fragments present in the molecules were compared with a library of substructure fragments to determine the toxic characteristics of each of the studied molecules as well as to predict toxicity activity. The results of this analysis are shown in Table 2, and indicate that piplartine shows greater toxicity and increased ability to bind to nuclear receptors than its analogues, effects that can be related to its cytotoxic effects observed during in vitro tests in mammalian cells. In addition, the Ames mutagenicity prediction revealed only positive for piplartine.

Table 1. Basic, geometric, structural, and solubility parameters of the parent and analogue compounds.

\begin{tabular}{|c|c|c|c|c|c|c|}
\hline Compounds & Piplartine & 19A & 14B & $6 B$ & $\mathbf{1 M}$ & 1G \\
\hline \multicolumn{7}{|c|}{ Basic properties } \\
\hline Atom count & 40 & 51 & 31 & 48 & 56 & 38 \\
\hline $\mathrm{Mw}$ & 315.32 & 287.31 & 432.48 & 387.39 & 239.27 & 359.42 \\
\hline \multicolumn{7}{|c|}{ Structural properties } \\
\hline Asymmetric atom count & 0 & 0 & 0 & 0 & 0 & 0 \\
\hline Rotatable bond count & 5 & 6 & 2 & 5 & 7 & 5 \\
\hline Ring count & 2 & 2 & 3 & 3 & 3 & 2 \\
\hline Aromatic ring count & 2 & 1 & 2 & 3 & 3 & 2 \\
\hline Hetero ring count & 1 & 1 & 2 & 0 & 0 & 1 \\
\hline Hydrogen bond donor count & 0 & 0 & 0 & 3 & 1 & 0 \\
\hline Hydrogen bond acceptor count & 5 & 5 & 2 & 5 & 5 & 4 \\
\hline Formal charge & 0 & 0 & 0 & 0 & 0 & 0 \\
\hline Fsp3 (a) & 0.18 & 0.40 & 0.13 & 0.00 & 0.12 & 0.19 \\
\hline Topological polar surface area $\left(\mathrm{A}^{2}\right)$ & 65.07 & 65.07 & 31.23 & 93.11 & 77.10 & 49.69 \\
\hline Molar refractivity $\mathrm{cm}^{3} / \mathrm{mol}$ & 87.42 & 101.15 & 70.63 & 112.82 & 123.64 & 79.89 \\
\hline Polarisability $\left(\mathrm{A}^{3}\right)$ & 32.54 & 38.29 & 26.66 & 41.46 & 46.66 & 30.59 \\
\hline \multicolumn{7}{|c|}{ Solubility parameters } \\
\hline $\log _{P}$ & 1.89 & 2.71 & 2.36 & 3.55 & 4.63 & 2.26 \\
\hline $\operatorname{Milog} p(b)$ & 2.19 & 2.78 & 4.69 & 5.02 & 2.86 & 2.90 \\
\hline $\log _{D} \mathrm{pH}$ range $1.7-8.0$ & 1.89 & 2.71 & 2.36 & 3.54 & 4.63 & 2.26 \\
\hline Intrinsic solubility & -3.01 & -4.53 & -2.87 & -4.73 & -5.48 & -2.81 \\
\hline Solubility category & High & Moderate & High & Low & Low & High \\
\hline $\log \mathrm{S} \mathrm{pH}$ range $1.7-8.0$ & -3.01 & -4.53 & -2.87 & -4.73 & -5.48 & -2.81 \\
\hline \multicolumn{7}{|c|}{ Geometry parameters } \\
\hline Van der Waals volume $\left(\AA^{3}\right)$ & 281.06 & 337.61 & 213.99 & 341.62 & 390.54 & 260.80 \\
\hline Volume $\left(\AA^{3}\right)(b)$ & 282.84 & 263.86 & 394.07 & 340.76 & 218.97 & 339.43 \\
\hline Van der Waals surface area $\left(\AA^{2}\right)$ & 425.62 & 543.27 & 333.75 & 515.78 & 620.14 & 423.69 \\
\hline Solvent accessible surface area $\left(\AA^{2}\right)$ & 549.15 & 659.24 & 445.82 & 631.17 & 725.57 & 577.96 \\
\hline Topological polar surface area $\left(\AA^{2}\right)$ & 65.07 & 65.07 & 31.2 & 93.11 & 77.10 & 49.69 \\
\hline Absorbance & $322 \mathrm{~nm}$ & $329 \mathrm{~nm}$ & $321 \mathrm{~nm}$ & $312 \mathrm{~nm}$ & $306.5 \mathrm{~nm}$ & $301.5 \mathrm{~nm}$ \\
\hline
\end{tabular}

(a) Number of sp3 carbons/number of carbons; (b) Molinspiration method. 19A, 14B, 6B, 1M, and 1G are analogue compounds of piplartine. Fraction of $\mathrm{sp}^{3}$ carbon atoms $\left(\mathrm{Fsp}^{3}\right)$. 
Table 2. Toxicity analysis and bioactivity prediction of the parent and analogue compounds against various drug targets.

\begin{tabular}{|c|c|c|c|c|c|c|}
\hline Compounds & Piplartine & 19A & 14B & $6 B$ & $1 \mathbf{M}$ & $1 G$ \\
\hline \multicolumn{7}{|l|}{ Toxicity prediction (c) } \\
\hline AMES toxicity & Yes & No & No & No & No & \\
\hline Max. tolerated dose (human) (0.505 $\log \mathrm{mg} / \mathrm{kg} /$ day) & 1.006 & 0.677 & 1.043 & 1.095 & 1.051 & 1.114 \\
\hline hERG I inhibitor & No & No & No & No & No & \\
\hline hERG II inhibitor & No & No & No & Yes & No & \\
\hline Oral Rat Acute Toxicity $\left(\mathrm{LD}_{50}\right)(2.661 \mathrm{~mol} / \mathrm{kg})$ & 2.268 & 2.295 & 2.413 & 2.195 & 2.37 & 2.389 \\
\hline Oral Rat Chronic Toxicity (LOAEL) (3.402 log mg/kg bw/day) & 1.64 & 1.787 & 1.812 & 2.455 & 2.388 & 1.592 \\
\hline Hepatotoxicity & No & Yes & No & Yes & Yes & No \\
\hline Skin sensitisation & No & No & No & No & No & No \\
\hline T. pyriformis toxicity $(0.285 \times \log \mu \mathrm{g} / \mathrm{L})$ & 1.138 & 1.359 & 2.004 & 0.437 & 0.658 & 1.591 \\
\hline Minnow toxicity $(5.577 \times \log \mathrm{mM})$ & 1.293 & 0.446 & 1.179 & -0.172 & -0.914 & 1.027 \\
\hline \multicolumn{7}{|l|}{ Predictive bioactivity $(b)$} \\
\hline GPCR ligand & 0.13 & 0.17 & 0.07 & -0.11 & -0.04 & -0.15 \\
\hline Ion channel modulator & -0.51 & -0.16 & -0.53 & -0.27 & -0.29 & -0.54 \\
\hline Kinase inhibitor & -0.13 & -0.12 & -0.13 & -0.20 & -0.09 & -0.14 \\
\hline Nuclear receptor ligand & -0.32 & -0.07 & -0.12 & -0.31 & & -0.31 \\
\hline Protease inhibitor & -0.40 & 0.02 & -0.39 & -0.38 & -0.33 & -0.48 \\
\hline Enzyme inhibitor & -0.02 & 0.05 & 0.24 & -0.17 & -0.12 & -0.00 \\
\hline
\end{tabular}

(a) Number of sp3 carbons/number of carbons; (b) Molinspiration method; (c) pkCSM. The Ames test is a widely employed method that uses bacteria to test whether a given chemical can cause mutations in the DNA of the test organism (Ames); The human ether-a-go-go-related gene (hERG); median lethal dose $\left(\mathrm{LD}_{50}\right)$; Lowest-Observed-Adverse-Effect Level (LOAEL); G-protein-coupled receptors (GPCR).

\subsection{Cytotoxicity Assay}

The cytotoxicity of piplartine and its analogues was evaluated by MTT assay in a murine fibroblast (NIH-3T3) cell line at concentrations from 25 to $800 \mu \mathrm{g} / \mathrm{mL}$. The results demonstrated that piplartine decreased cell viability after $24 \mathrm{~h}$ of exposure, exhibiting considerable toxicity (Figure 3). Analogues 1G, $14 \mathrm{~B}$, and $1 \mathrm{M}$ promoted a considerable reduction in cell viability at concentrations of 400 and $800 \mu \mathrm{g} / \mathrm{mL}$ when compared with piplartine. Furthermore, $1 \mathrm{G}$ and $14 \mathrm{~B}$ presented the highest $\mathrm{pD}_{2}$ and $\mathrm{E}_{\max }$ values when compared with the other analogues (Table 3). However, analogues 19A and 6B did not exert significant effects on mammalian cell viability at the tested concentrations when compared with the effects of piplartine (Figure 3). The $\mathrm{pD}_{2}$ values of $19 \mathrm{~A}$ and $6 \mathrm{~B}$ were estimated based on their respective $E_{\max }$ values, which were lower than $50 \%$ (Table 3), indicating lower cytotoxicity than piplartine and the other analogues. Thus, among the tested compounds, piplartine presented the highest toxicity. The dimethylsulphoxide (DMSO) vehicle control displayed no effect on cell viability.

Table 3. Determination of $\mathrm{pD}_{2}$ and $\mathrm{E}_{\max }$ for the cytotoxic effect of piplartine and its analogues in murine fibroblast (NIH-3T3) cells.

\begin{tabular}{ccc}
\hline Compounds & $\mathrm{pD}_{\mathbf{2}}\left(-\log \mathrm{IC}_{\mathbf{5 0}}\right)^{\mathrm{a}}$ & $\mathbf{E}_{\max }(\mathbf{\%})^{\mathbf{b}}$ \\
\hline 19A & $-3.06 \pm 0.15$ & $37.93 \pm 2.85$ \\
1G & $-2.00 \pm 0.03$ & $95.69 \pm 0.79$ \\
1M & $-2.31 \pm 0.04$ & $70.94 \pm 1.20$ \\
14B & $-1.95 \pm 0.04$ & $83.64 \pm 0.47$ \\
6B & $-2.80 \pm 0.08$ & $47.93 \pm 2.52$ \\
Piplartine & $5.68 \pm 2.95$ & $96.94 \pm 0.12$ \\
\hline
\end{tabular}

${ }^{a}$ Negative logarithm of the mean inhibitory concentration $\left(\mathrm{IC}_{50}\right) ;{ }^{\mathrm{b}} \mathrm{E}_{\max }$ : decrease in cell viability at the maximum concentration tested $(800 \mu \mathrm{g} / \mathrm{mL})$. 
A
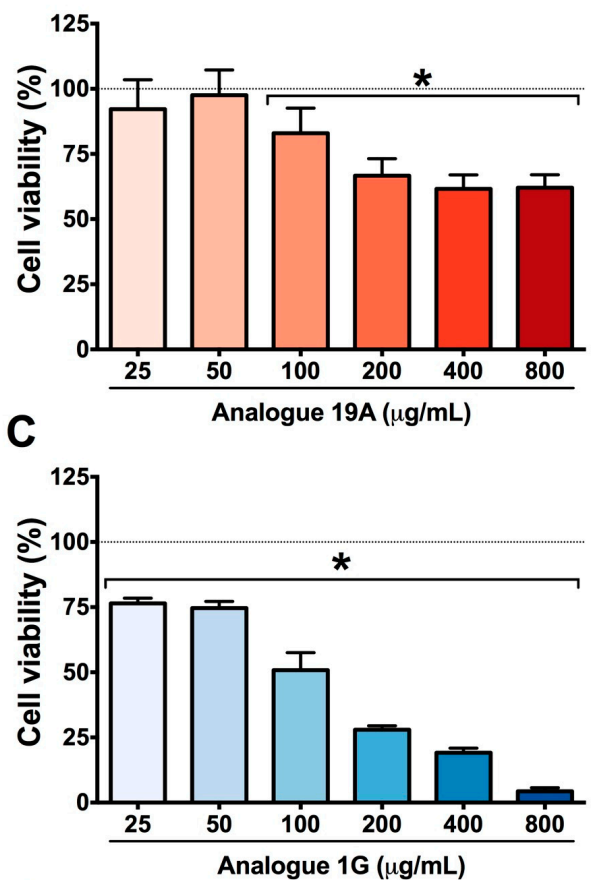

E

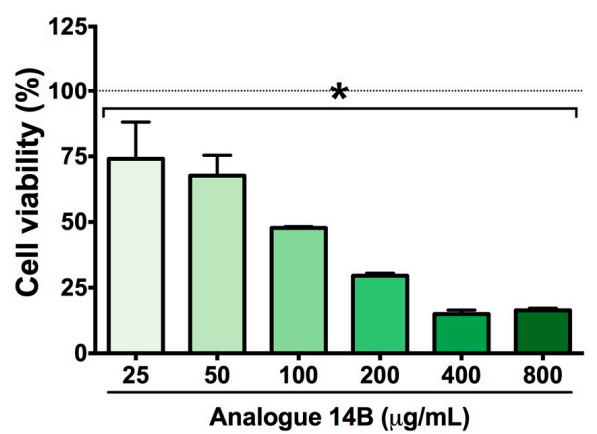

B
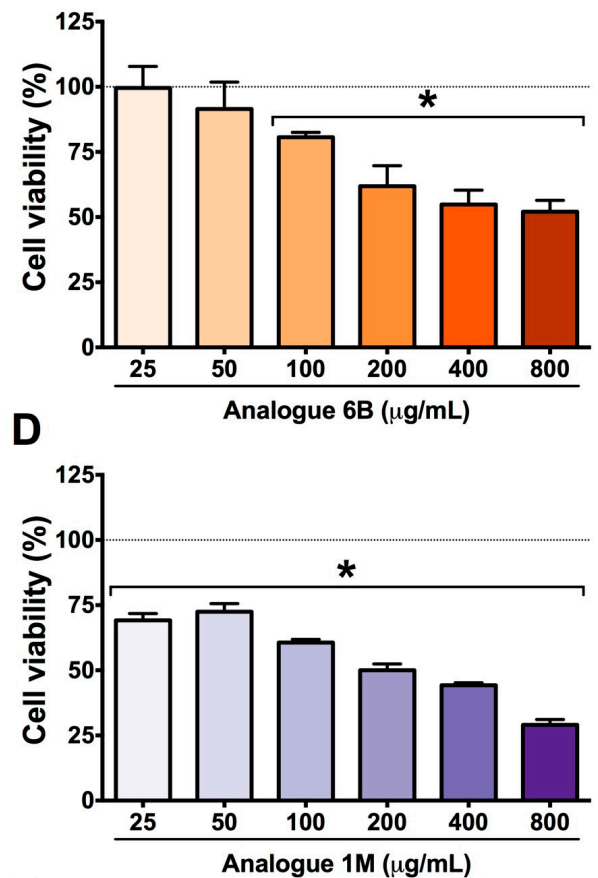

$\mathbf{F}$

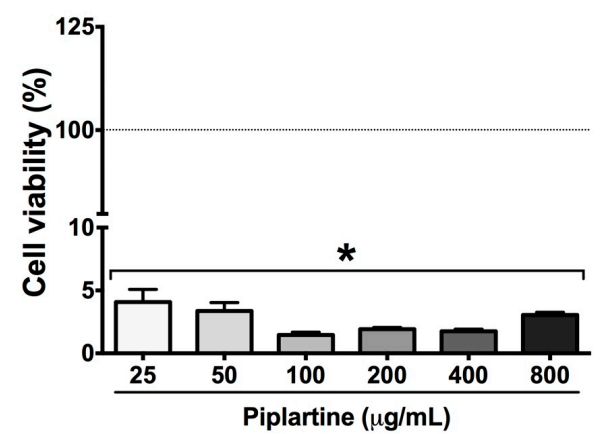

Figure 3. Cytotoxicity evaluation using the MTT method in murine fibroblast (NIH3T3) cells after exposure for $24 \mathrm{~h}$ to piplartine analogues (A) 19A $(72-2331 \mu \mathrm{M}),(\mathbf{B}) 6 \mathrm{~B}(62-1998 \mu \mathrm{M}),(\mathrm{C})$ 1G (85-2738 $\mu \mathrm{M}),(\mathbf{D}) 1 \mathrm{M}(56-1796 \mu \mathrm{M}),($ E) $14 \mathrm{~B}(101-3250 \mu \mathrm{M})$ and (F) piplartine (78-2514 $\mu \mathrm{M})$. Molecules were used at the same concentrations range at $\mu \mathrm{g} / \mathrm{mL}$ for all samples (25-800). Dimethyl sulfoxide (DMSO) was used as a negative control. The values are expressed as mean \pm SEM. ${ }^{*} p<0.05$ vs. DMSO control group. The dotted lines mark the $100 \%$ viability level.

The cytotoxicity of piplartine and its analogues was also evaluated by flow cytometry in a mouse BALB/cN macrophage (J774A.1) cell line at concentrations of 25, 100 and $400 \mu \mathrm{g} / \mathrm{mL}$ with exposure for $24 \mathrm{~h}$ (Figure 4). The DMSO vehicle control caused a significant $(p<0.05)$ reduction in cell viability, similar to the hydrogen peroxide $\left(\mathrm{H}_{2} \mathrm{O}_{2}\right)$ cell death control. Piplartine significantly $(p<0.05)$ affected cell viability at concentrations of 25 and $100 \mu \mathrm{g} / \mathrm{mL}$ when compared with a DMEM untreated control. Analogue $1 \mathrm{M}$, at all tested concentrations, and analogue $1 \mathrm{G}$ at $100 \mu \mathrm{g} / \mathrm{mL}(342 \mu \mathrm{M})$ significantly altered $(p<0.05)$ cell viability in comparison with the negative control, but not in a toxic manner. Other analogues did not show significant effects on cell viability. Interestingly, treatment with piplartine and its analogues appeared to reduce the cytotoxicity of the DMSO vehicle on J774A.1 cells. 
A

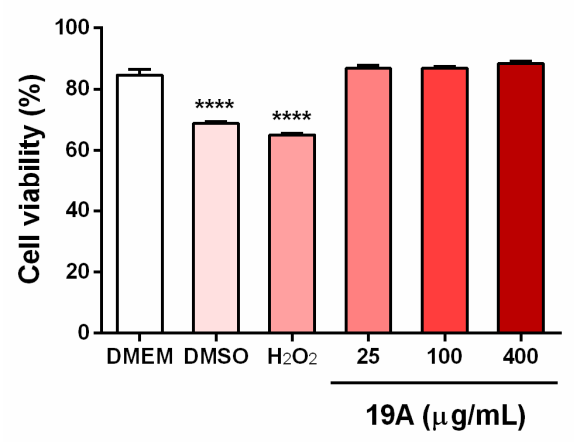

C

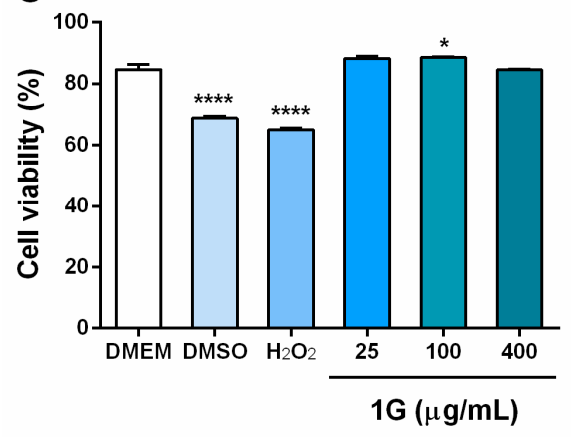

E

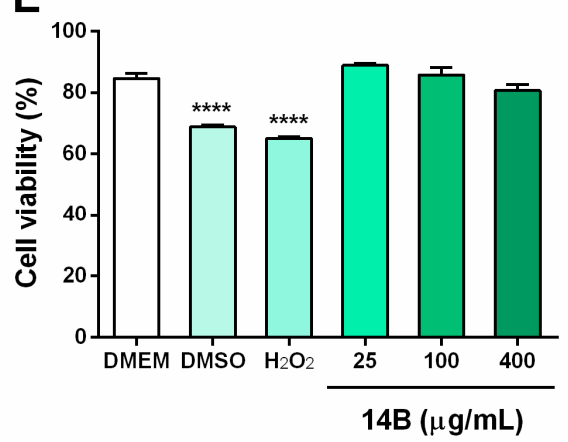

B

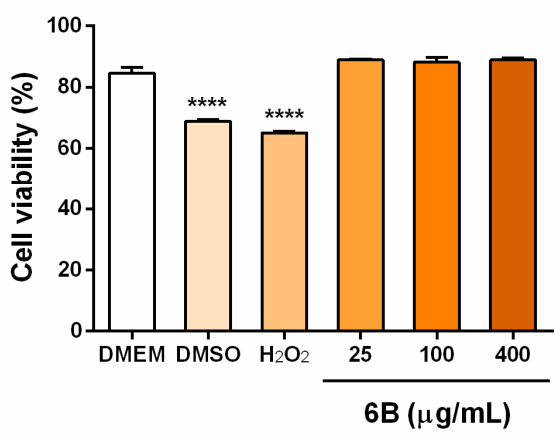

D

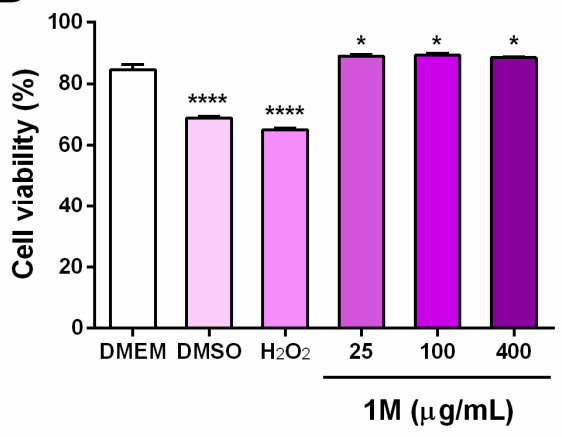

F

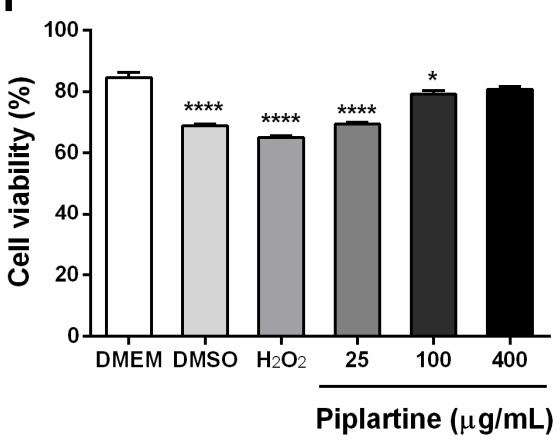

Figure 4. Cytotoxicity evaluation in the mouse BALB/cN macrophage (J774A.1) cell line following exposure for $24 \mathrm{~h}$ to piplartine analogues (A) 19A (72, 291 and $1165 \mu \mathrm{M}),(\mathrm{B}) 6 \mathrm{~B}(62,249$ and $999 \mu \mathrm{M})$, (C) $1 \mathrm{G}(85,342$ and $1369 \mu \mathrm{M}),(\mathrm{D}) 1 \mathrm{M}(56,224$ and $898 \mu \mathrm{M}),(\mathrm{E}) 14 \mathrm{~B}(101,406$ and $1625 \mu \mathrm{M})$ and (F) piplartine $(78,314$ and $1257 \mu \mathrm{M})$. Molecules were used at the same concentrations range at $\mu \mathrm{g} / \mathrm{mL}$ for all samples (25, 100 and 400). Dulbecco's Modified Eagle Medium (DMEM) was used as a negative control. Cells were analysed by flow cytometry (20,000 events/sample). The values are expressed as mean \pm SEM. ${ }^{*} p<0.05$ and ${ }^{* * *} p<0.0001$ vs. DMEM control group.

In the same cell viability assay, the percent of non-viable cells was analysed regarding the cytotoxic mechanism in mammalian cells using annexin- $V$ conjugated to green-fluorescent FITC and propidium iodide (PI) staining to distinguish apoptotic cells (annexin-V FITC) from necrotic cells (PI) by flow cytometry (Figure 5 and Figure S2). As expected, the control of cell death by apoptosis $\left(\mathrm{H}_{2} \mathrm{O}_{2}\right)$ showed a significant $(p<0.05)$ increase in annexin-V FITC fluorescence intensity compared with the DMEM negative control. A significant $(p<0.05)$ increase in annexin-V FITC staining was observed in J774A.1 cells following treatment with piplartine $25 \mu \mathrm{g} / \mathrm{mL}(785 \mu \mathrm{M})$ and analogue $14 \mathrm{~B}$ at $400 \mu \mathrm{g} / \mathrm{mL}$ (1625 $\mu \mathrm{M}$ ) when compared with the DMEM negative control. Furthermore, significant $(p<0.05)$ differences between the annexin-V FITC and PI fluorescent signals were observed for each group of 
J774A.1 cells treated with piplartine and its analogues, indicating that apoptosis was the principal mechanism of cell death.

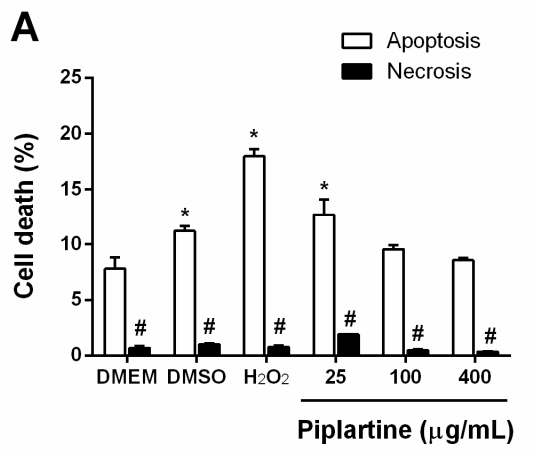

C
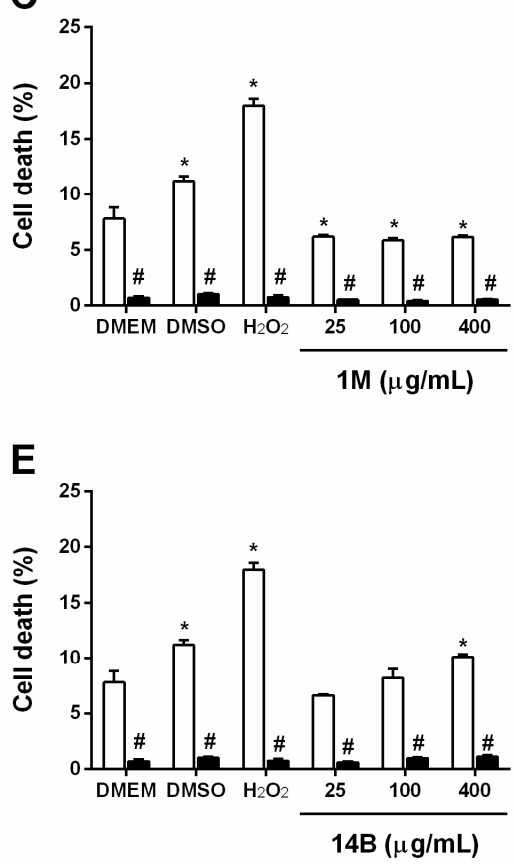

B

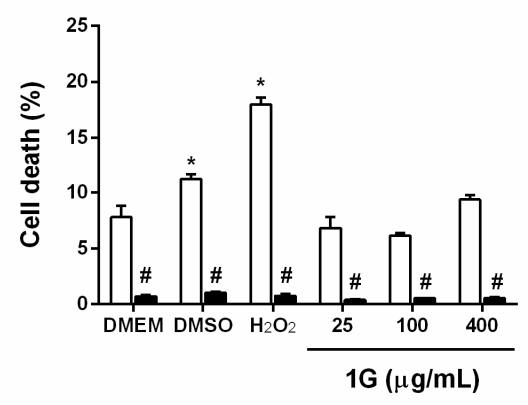

D

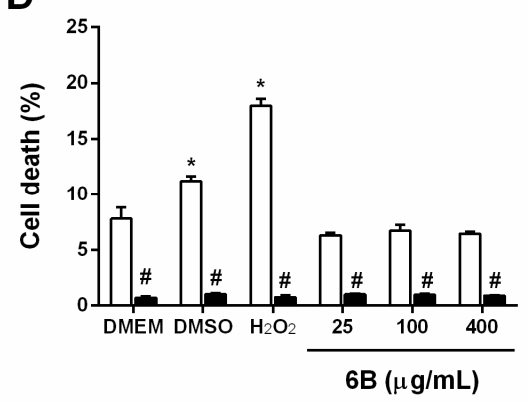

$\mathbf{F}$

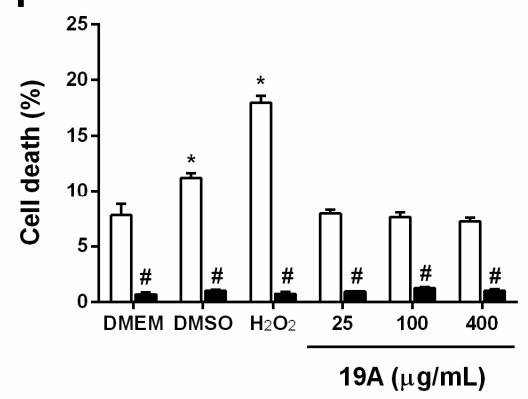

Figure 5. Evaluation of the cell death mechanism mediated by (A) piplartine (78, 314 and $1257 \mu \mathrm{M})$ and its analogues (B) 1G (85, 342 and $1369 \mu \mathrm{M}),(\mathrm{C}) 1 \mathrm{M}(56,224$ and $898 \mu \mathrm{M}),(\mathrm{D}) 6 \mathrm{~B}(62,249$ and $999 \mu \mathrm{M})$, (E) 14B (101, 406 and $1625 \mu \mathrm{M})$ and (F) 19A (72, 291 and $1165 \mu \mathrm{M})$ in J774A.1 cells following treatment for $24 \mathrm{~h}$ at the same concentrations range at $\mu \mathrm{g} / \mathrm{mL}$ for all samples $(25,100$ and 400$)$ using annexin-V FITC (apoptosis marker) and propidium iodide (PI, necrosis marker) staining. Cells were analysed by flow cytometry (20,000 events/sample). The values are expressed as mean \pm SEM. ${ }^{*} p<0.05$ vs. DMEM untreated control group. \# $p<0.05$ vs. apoptosis staining from each respective group.

\subsection{In Vitro Experiments in Adult Worms of S. mansoni}

The activity of the amide piplartine and its analogues against adult worms of $S$. mansoni aged 49 days was most prominent at the concentration of $10 \mu \mathrm{M}$ and incubation time of $96 \mathrm{~h}$ (Table 4). The amide piplartine showed activity against the parasite $24 \mathrm{~h}$ after incubation, while its analogues showed no activity at the tested concentrations when compared with piplartine, as noted in Table S1. 
Table 4. In vitro effects of compounds in 49-day-old S. mansoni worms.

\begin{tabular}{|c|c|c|c|c|c|c|c|}
\hline \multirow{3}{*}{ Group } & \multirow{3}{*}{$\begin{array}{l}\text { Period of Incubation } \\
\text { (h) }\end{array}$} & \multirow{2}{*}{\multicolumn{2}{|c|}{ Dead Worms $(\%)^{a}$}} & \multicolumn{4}{|c|}{ Motor Activity Reduction (\%) a } \\
\hline & & & & \multicolumn{2}{|c|}{ Slight } & \multicolumn{2}{|c|}{ Significant } \\
\hline & & $\mathbf{M}$ & $F$ & $\mathbf{M}$ & $F$ & $\mathbf{M}$ & F \\
\hline \multirow{4}{*}{ Control ${ }^{b}$} & 24 & 0 & 0 & 0 & 0 & 0 & 0 \\
\hline & 48 & 0 & 0 & 0 & 0 & 0 & 0 \\
\hline & 72 & 0 & 0 & 0 & 0 & 0 & 0 \\
\hline & 96 & 0 & 0 & 0 & 0 & 0 & 0 \\
\hline \multirow{4}{*}{$0.5 \%$ DMSO } & 24 & 0 & 0 & 0 & 0 & 0 & 0 \\
\hline & 48 & 0 & 0 & 0 & 0 & 0 & 0 \\
\hline & 72 & 0 & 0 & 0 & 0 & 0 & 0 \\
\hline & 96 & 0 & 0 & 0 & 0 & 0 & 0 \\
\hline Praziquantel & 24 & 100 & 100 & 0 & 0 & 100 & 100 \\
\hline \multirow{3}{*}{$2 \mu \mathrm{M}$} & 48 & 100 & 100 & 0 & 0 & 100 & 100 \\
\hline & 72 & 100 & 100 & 0 & 0 & 100 & 100 \\
\hline & 96 & 100 & 100 & 0 & 0 & 100 & 100 \\
\hline Amide piplartine & 24 & 100 & 100 & 0 & 0 & 100 & 100 \\
\hline $10 \mu \mathrm{M}$ & 48 & 100 & 100 & 0 & 0 & 100 & 100 \\
\hline \multirow{6}{*}{$5 \mu \mathrm{M}$} & 72 & 100 & 100 & 0 & 0 & 100 & 100 \\
\hline & 96 & 100 & 100 & 0 & 0 & 100 & 100 \\
\hline & 24 & 0 & 0 & 100 & 100 & 0 & 0 \\
\hline & 48 & 0 & 0 & 100 & 100 & 0 & 0 \\
\hline & 72 & 0 & 0 & 100 & 100 & 0 & 0 \\
\hline & 96 & 60 & 60 & 0 & 0 & 60 & 60 \\
\hline
\end{tabular}

a Percentages relative to the 20 worms investigated; ${ }^{b}$ RPMI 1640 . The effect of the compounds on motor activity of adult S. mansoni was assessed qualitatively. Male (M) and Female (F).

\section{Discussion}

Schistosomiasis is a global public health problem, and the search is ongoing for drugs to treat this neglected disease and meet the requirements of the standard treatment, praziquantel. Because it is a safe medication when administered to children, adults, the elderly and pregnant women, with low toxicity and few side effects, the use of praziquantel has been increasing, despite the number of patients who are resistant to the drug. Thus, the development of new anthelmintic compounds to treat schistosomiasis has become a major research objective $[6,20]$.

Natural products represent an alternative to conventional therapeutic compounds because of the diversity in molecules and biological activities that these products present. Biodiversity results a large number of compounds with activities that are as yet unknown. Despite advancements in biotechnology, genomics and medicinal chemistry, the discovery of new drugs for the treatment of schistosomiasis remains challenging, since in addition to biological activity, drugs are required to have low toxicity $[6,21]$. In this context, the objective of this work was to study the schistosomicidal activity and cytotoxicity of piplartine and its synthetic analogues, and to compare the analogues to the parent compound.

An alternative strategy to minimise drug resistance is the chemical synthesis of established drugs or natural compounds with activities previously described in the literature, where chemical-structural modifications are made in functional groups that may be responsible for biological activity [6]. These modifications can increase, decrease or abolish biological activity; in some instances, these changes can promote decreased toxicity, but with an associated loss of biological activity. The structural changes made to piplartine to produce the analogues in this study resulted in a loss of activity against $S$. mansoni and a decrease in toxicity. Studies show that phenotypic analysis remains the optimal approach to the screening of anthelmintics as it is a simple and low-cost, qualitative strategy, widely used in in vitro testing [22,23].

Several studies have demonstrated the activity of a range of natural products against $S$. mansoni, although the mechanism of action of these compounds remains unknown, such as, piplartine, which is highly active against this parasite [15]. Previous results have shown that piplartine promotes changes in motility, instigating the death of the parasite, and that no difference in response was observed 
between male and female parasites [15]. According to the theoretical data shown in Figure 1, piplartine presents a higher electron density around the molecule, with a dipole moment of 5.47, which may influence its anthelmintic activity.

It is necessary for a drug to go to the market that the drug has good ADMET (absorption, distribution, metabolism, excretion, toxicity) properties. Drug toxicology is one of the crucial research fields in the preclinical study. Toxicity is a leading cause of attrition at all stages of drug development. In silico prediction of compound toxicity which can reduce the expenses of the company and save a lot of time has attracted considerable attention [24].

Compound 1G did not exhibit antischistosome activity at the concentrations tested. As shown in Figure 1, this compound had a low electron density, presenting a very low dipole moment when compared with piplartine. Changes in the functional groups of a molecule can influence its biological activity, and in this compound, modifications were observed in the dihydropiperidinone ring, which was replaced by piperidinyl [25].

Compounds 14B and 19A have similar electron densities, based on their dipole moment values, which are close to that of piplartine. The 19A molecule has a double bond between the rings that underwent modifications, as well as a change in the aliphatic chain between these two rings. Compound 14B underwent a dihydropiperidinone modification, being replaced with a piperidinyl ring, and in the trimethoxybenzene moiety, substitution with a benzodioxol ring quashed the schistosomicidal activity of this derivative [25]. These compounds have high electron densities and are highly similar to piplartine but are large and bulky compounds when compared with their prototype. These features may explain their lack of interaction with enzymes and ion channel receptors in the parasite, promoting the loss of biological activity against $S$. mansoni when compared with piplartine, whereas piplartine at low concentrations promotes alteration of the parasite tegument. Compound $14 \mathrm{~B}$ has a double bond between the two altered portions, thus increasing the distance between the two rings forming the compound, which may have influenced the loss of this biological activity.

Compounds $1 \mathrm{M}$ and $6 \mathrm{~B}$ present electronic densities similar to piplartine, according to Figure 1 , but did not present biological activity against the $S$. mansoni parasite. This loss in activity may be related to the large size of these molecules, which prevents binding to enzymes that are in the tegument, meaning that these molecules are unable to promote the necessary modifications in the membrane of the parasite tegument leading to the death of the parasite. In the compound $1 \mathrm{M}$, the dihydropiperidinone moiety has been replaced by a trimethoxybenzene ring and the trimethoxybenzene moiety has been replaced by a dicyclohexyl ring. This change in the position of the trimethoxybenzene ring may influence the biological response by causing this compound to lose its activity against the parasite. In compound 6B, the trimethoxybenzene is replaced by a dicyclohexyl ring, as in compound $1 \mathrm{M}$, which may promote the loss of activity against $S$. mansoni parasite when compared with piplartine, because both of these compounds, with this same alteration, lost biological activity.

Complementary studies are still required to determine the relationship between the chemical structure and biological activities of piplartine and its analogues to facilitate the discovery of new prototypes from piplartine. The substitution of a hydrogen atom with a different functional group such as methoxyl, nitro, halogen or others may alter the biological activity, and this may subsequently promote changes in the duration and nature of the pharmacological effect as well as in the physicochemical characteristics of the molecules, thus contributing to the production of new molecules. From this study, it can be observed that functional groups trimethoxybenzene and dihydropiperidinone are important for promoting schistosomicidal activity, because their removal or alteration in modified analogues resulted in the loss of biological activity as well as the toxicity of the compound [26].

In murine fibroblast cells, piplartine showed toxicity at all concentrations tested while compounds $1 \mathrm{G}$ and 14B, but not the other derivatives, showed toxicity at 200, 400 and $800 \mu \mathrm{g} / \mathrm{mL}$. As shown by the solubility parameters (Table 1), ultraviolet and visible light absorption spectra of piplartine and its analogues it was possible to observe that the analogues present values close to that of piplartine, 
indicating that there are similarities of functional groups between these molecules (Table 1 and Figure 2),; these compounds presented values close to that of piplartine, and the toxicity analysis and bioactivity prediction (Table 2) showed that these synthetic compounds were again similar to piplartine, thus explaining their toxicity. Similarly, flow cytometry cytotoxicity assays in mouse $\mathrm{BALB} / \mathrm{cN}$ macrophages showed that piplartine was more toxic to mammalian cells than the analogues. However, a marked reduction in the cytotoxicity mediated the by DMSO vehicle was observed in cells treated with piplartine and the analogues, indicating not only that the molecules modulated the toxic effect in mammalian cells but also that they had a protective effect.

Annexin-V FITC/PI staining was used to determine the cell death mechanism observed in the cytotoxicity assays by flow citometry. Recombinant annexin- $V$ conjugated to FITC identifies exposed phosphatidylserine on the inner membrane and is used to detect the initial phase of apoptosis [27], while PI, a red-fluorescent nucleic acid probe to which living cells are impermeable, can be used to detect necrotic cells [28]. In this study, piplartine- and analogue-treated J774A.1 cells showed increased annexin-V FITC staining after $24 \mathrm{~h}$ compared to that after PI staining, suggesting that the mechanism of cell death was related to apoptosis [29]. Apoptosis is characterized by cell shrinkage, chromatin condensation and systematic DNA cleavage in a controlled way which prevents the inflammatory process [30]. These data indicate the potential of a rational design of bioactive molecules with low toxicity from piplartine, while further studies are required.

Studies show that the biological and toxicological activity of piplartine can be attributed to the presence of the $\alpha, \beta$ unsaturated carbonyl groups, where the substitution of any of these unsaturated groups leads a molecule without cytotoxicity and to the loss of biological activity $[14,31,32]$. Research using this compound has indicated that the $\alpha, \beta$ unsaturated groups in the aliphatic chain present between the two rings are important for the biological activity against $S$. mansoni as they maintain the conformational arrangement of the two rings, whereas changes in this arrangement decrease cytotoxicity. This effect was observed in the compounds synthesised without the double bond.

This study shows that the modification of piplartine to produce its derivatives resulted in the loss of schistosomicidal activity, indicating that the functional groups trimethoxybenzene and dihydropiperidinone are essential. The synthesis approach used promoted alterations in conformational arrangements, the hydrophilic-lipophilic balance, and the distribution of electronic density compared to those of piplartine. Modifications to trimethoxybenzene and the aliphatic chain were the most significant, as changes to the methoxyl radical in the meta position of the aromatic ring promoted the loss of schistosomicidal activity and subsequent reduction in toxicity.

\section{Materials and Methods}

\subsection{Piplartine and Synthetic Analogues}

Roots of Piper tuberculatum were harvested on the campus of the University of São Paulo (USP), São Paulo, Brazil. Botanical classification was performed by Elsie Franklin Guimarães (Instituto de Pesquisas Jardim Botânico do Rio de Janeiro). A voucher specimen (Kato-0169) has been deposited at the herbarium of the same institute. Piplartine was isolated from the dry roots of P. tuberculatum according to a published procedure [25]. Purity was determined by reversed-phase chromatography (RP-HPLC) and the structure by proton nuclear magnetic resonance (1H-NMR) as described also in the supplemental material section (Figure S1).

The cinnamides $1 \mathrm{G}$ and $14 \mathrm{~B}$ were synthesised by adding triethylamine ( 3 equivalent) and amine (pyrrolidine) to a solution of acid chloride (1 equiv) in $\mathrm{CH}_{2} \mathrm{Cl}_{2}$. To prepare the acid chloride, a solution of 3,4,5-trimethoxycinnamic acid and 3,4-methylenedioxy cinnamic acid (1 equiv.) (Sigma Aldrich, St. Louis, MO, USA) in dry tetrahydrofuran (THF) $(10 \mathrm{~mL})$, kept under nitrogen atmosphere, and oxalyl chloride (5 equiv.) was added dropwise and stirred at room temperature for 5-6 h. Excess oxalyl chloride was then removed under reduced pressure, yielding the corresponding acid chloride. The reaction mixture was stirred overnight at room temperature, and quenched with 
saturated aqueous $\mathrm{NH}_{4} \mathrm{Cl}$, and extracted with $\mathrm{CH}_{2} \mathrm{Cl}_{2}$ (three times). The combined organic phases were washed with brine and dried over $\mathrm{MgSO}_{4}$. After filtration and concentration, the residue was purified by flash chromatography to provide the desired amide [33].

Compounds $1 \mathrm{M}$ and $6 \mathrm{~B}$ were synthesised by adding to a solution of 2E-3,4,5-trimethoxycinnamic acid and 4-nitrocinnamic acid (1 equiv.) in THF 0.9 equiv. of $N, N^{\prime}$-dicyclohexylcarbodiimide (DCC). The reaction mixture was stirred overnight at room temperature and dried on a rotary evaporator to remove any remaining solvent. The product was dissolved in (dichloromethane) DCM, a saturated solution of $\mathrm{NaHCO}_{3}$ was added, and the resulting solution was washed three times with DCM. The organic phase was combined, dried with $\mathrm{MgSO}_{4}$, filtered, and concentrated under pressure. The obtained crystalline product was then recrystallised on hot methanol or purified by chromatography $[25,33]$.

Compound 19A was obtained by adding to a solution of acid chloride (1 equiv.) in THF 1 equiv. butanol. The 2E,4E-5-3,4,5-trimethoxyphenyl penta-2,4-dienoic acid was synthetised as described previously [34].

\subsection{Theoretical Calculations}

Density Functional Theory (DFT) [35] calculations were performed to determine the energy of the frontier orbitals with b3lyp [36] and basis set 6-311g with two polarisation functions $(\mathrm{d}, \mathrm{p})$ and diffuse functions for hydrogen (++), using Gaussian 09 software (Gaussian Inc., Wallingford, CT, USA) for theoretical calculations [37]. Dipole moment structures were calculated to determine electron density using GaussView 5.0 software (Gaussian Inc., Wallingford, CT, USA).

\subsection{UV-Vis Absorption Spectra}

Ultraviolet and visible light (UV-Vis) absorption spectra of piplartine and its analogues were obtained with a UV-1280 spectrophotometer (Shimadzu, Kyoto, Japan). Purified piplartine and its analogues $(1 \mathrm{G}, 1 \mathrm{M}, 6 \mathrm{~B}$ and $14 \mathrm{~B})$ were solubilised in HPLC-grade acetonitrile and diluted to a concentration of $15 \mu \mathrm{g} / \mathrm{mL}$. Because of its high absorbance and low solubility, the 19A analogue was further diluted to $7.5 \mu \mathrm{g} / \mathrm{mL}$ before measurement. Scans were performed using a quartz cuvette with a path length of $1 \mathrm{~cm}$ in the $200-450 \mathrm{~nm}$ range against a baseline recorded with acetonitrile at room temperature.

\subsection{In Silico Physicochemical and Toxicity Studies}

Two-dimensional structures were designed using Marvin Sketch 17.4.3, 2017, ChemAxon (Available online: http://www.chemaxon.com). 3D structures were geometrically optimised using Another Molecular Modeling Program-Vis (AMMP-Vis) (AMMP 2.0, Monterey, CA, USA), a full-featured molecular dynamics program for manipulating both small molecules and macromolecules including proteins, nucleic acids, and other polymers [38]. Ammp-Mon charges were added and an assisted model building with energy refinement (AMBER) field force was applied to minimise the energy conformation using a genetic algorithm with 3000 steps, applying the water dielectric constant. The conformational search was performed using the Boltzmann jump method, with flexible and psi torsions, at $300 \mathrm{~K}$, and with dielectric constant equal to 80,000 and root mean squared deviation RMSD equal to 60.00 .

Physicochemical properties were also calculated, including molecular weight (MW), lipophilicity $\left(\log _{P}\right)$, octanol-water coefficient solubility $(\log \mathrm{D})$, water solubility $(\log S)$, rotatable bonds, topological polar surface area (tPSA), number of hydrogen bond acceptors and number of hydrogen bond donors using Chemicalize, a web tool to predict basic, geometric, structural and solubility parameters, Calculation, August/2017, (Available online: https://chemicalize.com/; developed by ChemAxon (Available online: http://www.chemaxon.com)). 
The toxicity analyses were performed by pkCSM $[39,40]$. The biological activity of the parent drug and related compounds was predicted using the Molinspiration web server (http://www. molinspiration.com/).

\subsection{Cytotoxicity Assay}

\subsubsection{NIH3T3 and J774A.1 Cell Culture}

Murine fibroblast (NIH3T3) cells were acquired from the cell bank of Rio de Janeiro (Rio de Janeiro, Brazil), and the murine BALB/cN macrophage (J774A.1, TIB-67 $\left.{ }^{\mathrm{TM}}\right)$ (ATCC ${ }^{\circledR}$, Washington, DC, USA). Cells were cultured in Dulbecco's Modified Eagle's Medium (DMEM) (Gibco BRL, Grand Island, NY, USA) supplemented with $10 \%$ heat inactivated foetal bovine serum (Life, USA) and $1 \%$ antibiotic solution (100 IU $/ \mathrm{mL}$ penicillin $/ 100 \mu \mathrm{g} / \mathrm{mL}$ streptomycin, Life, USA) at $37^{\circ} \mathrm{C}$ and $5 \% \mathrm{CO}_{2}$.

\subsubsection{Cell Viability Assays}

Viability assays were performed by the MTT (3-[4,5-dimethylthiazol-2-yl]-2,5-diphenyltetrazolium bromide) dye reduction method. NIH3T3 cells were seeded into 96-well culture plates at a density of $3 \times 10^{3}$ cells in DMEM culture medium overnight at $37^{\circ} \mathrm{C}$ and $5 \% \mathrm{CO}_{2}$ in a humid atmosphere. Next, the medium was removed and various concentrations $(25-800 \mu \mathrm{g} / \mathrm{mL})$ of samples reconstituted in $3 \%$ DMSO were applied. DMSO (3\%) was used as a control. The plates were incubated for $24 \mathrm{~h}$ [28]. Next, $15 \mu \mathrm{L}$ of MTT solution ( $5 \mathrm{mg} / \mathrm{mL}$ in phosphate buffer) was added to each well and the plates were incubated for $2 \mathrm{~h}$. Medium was discarded and $100 \mu \mathrm{L}$ of DMSO was added to each well. Absorbance was determined using a spectrophotometer with a microplate reader at $595 \mathrm{~nm}$ (Molecular Devices Corporation, Sunnyvale, CA, USA).

For viability assays by flow cytometry method, J774A.1 cells were seeded into 96 -well culture plates at a density of $1.0 \times 10^{5}$ cells in DMEM culture medium for $2 \mathrm{~h}$ at $37{ }^{\circ} \mathrm{C}$ and $5 \% \mathrm{CO}_{2}$ in a humid atmosphere, and samples reconstituted in $1 \%$ DMSO were added to final concentrations of 25 ,

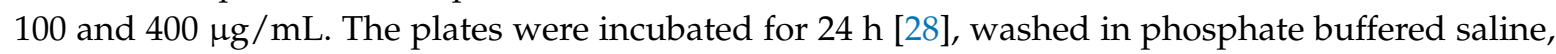
and resuspended in $100 \mu \mathrm{L}$ of binding buffer $(10 \mathrm{mM}$ (4-(2-hydroxyethyl)-1-piperazineethanesulfonic acid) HEPES buffer $\mathrm{pH} 7.4,140 \mathrm{mM} \mathrm{NaCl}$, and $2.5 \mathrm{mM} \mathrm{CaCl}_{2}$ ). Cells were then treated with $2 \mu \mathrm{L}$ of annexin-V FITC (Apoptosis Detection Kit; BD Biosciences, Franklin Lakes, NJ, USA) and $2 \mu \mathrm{L}$ of propidium iodide (PI, $50 \mu \mathrm{g} / \mathrm{mL}$ ) for $15 \mathrm{~min}$ in the dark at room temperature. Next, $100 \mu \mathrm{L}$ binding buffer was added and samples were analysed by flow cytometry (BD LSFortessa ${ }^{\mathrm{TM}}$, Franklin Lakes, NJ, USA). A total of 20,000 events were collected per sample.

\subsection{Animals and Parasites}

The Belo Horizonte (BH) strain of S. mansoni was maintained in Biomphalaria glabrata snails and Mesocricetus auratus hamsters at the Adolfo Lutz Institute (São Paulo, Brazil) according to standard procedures. Detailed methods for the infection of molluscs and hamsters, as well as for the recovery of parasites, were as described previously [41]. Briefly, the intermediate host snails were exposed to light for approximately $3 \mathrm{~h}$ and cercariae of $S$. mansoni were subsequently harvested. Hamsters (aged 3 weeks, weight $25 \mathrm{~g}$ ) were infected subcutaneously with 150 cercariae and, 49 days post-infection, adult S. mansoni specimens were recovered from each hamster by perfusion with Roswell Park Memorial Institute (RPMI) medium 1640 medium (Invitrogen, São Paulo, Brazil) and heparin. This study was approved by the Institutional Review Board of the Guarulhos University (São Paulo, Brazil; approval number 31/17, 20 March 2017). All animals were handled in strict accordance with good animal practice as defined by the Animal Use Ethics Committee.

\subsection{Adult Schistosomes}

The preparations and culture of schistosomes was performed as previously described [42,43]. Briefly, hamsters were killed 49 days after infection for the recovery of adult schistosomes. Next, fresh 
adult worm pairs (male and female) were washed and placed in a 24-well culture plate (TPP, St. Louis, MO, USA) containing RPMI 1640 medium supplemented with 10\% foetal bovine serum (Gibco-BRL, Life Technologies do Brazil Ltda, Sao Paulo, SP, Brazil), $200 \mu \mathrm{g} / \mathrm{mL}$ streptomycin, and $200 \mathrm{IU} / \mathrm{mL}$ penicillin (Invitrogen, São Paulo, SP, Brazil) at $37^{\circ} \mathrm{C}$ in a $5 \% \mathrm{CO}_{2}$ atmosphere. Adult schistosomes were maintained continuously in medium (with or without drugs) for $96 \mathrm{~h}$ as described below.

\subsection{In Vitro Experiments with Adult Worms of S. mansoni}

In vitro assays in S. mansoni adults were performed with mated males and females. The worm pairs obtained from the infusion hamsters were washed twice with RPMI 1640 medium containing $200 \mathrm{U} / \mathrm{mL}$ penicillin, $200 \mu \mathrm{g} / \mathrm{mL}$ streptomycin and $2 \mu \mathrm{g} / \mathrm{mL}$ amphotericin B (Vitrocell, Campinas, Brazil). The mated parasites were then transferred into 24-well cell culture plates (TPP, St. Louis, MO, USA) containing, per well, 1 pair of worms in $2 \mathrm{~mL}$ of RPMI 1640 medium supplemented with $10 \%$ foetal bovine serum and buffered with $25 \mathrm{mM}$ HEPES. Worms were incubated with the amide pyramethrin analyzes at different concentrations (50,25, 10 and $5 \mu \mathrm{M}) ; 5$ and $10 \mu \mathrm{M}$ piplartine for up to $96 \mathrm{~h} ; 2 \mu \mathrm{M}$ praziquantel was used as positive control and culture medium was used as a negative control [44].

Cultures of adult worms were monitored by microscopy or magnifying glass. The effect of the drug was assessed with emphasis on changes in worm motor activity and death of worms as previously described [45-47]. The mortality of worms was judged by the absence of movement for 2 min or when touched with forceps.

\subsection{Statistical Analysis}

Statistical analysis was performed by analysis of variance (ANOVA) and Bonferroni post hoc test using Graph Pad Prism 5.03 (GraphPad Software, La Jolla, CA, USA) to evaluate the statistical significance of differences between control and treated cells in cytotoxicity assays. All values were expressed as means \pm standard error of the mean (SEM) from triplicates in three independent experiments, and a value of $p<0.05$ was considered statistically significant.

\section{Conclusions}

This study demonstrated that analogues of piplartine, when compared with the parent molecule, showed a loss of activity against the $S$. mansoni parasite, but showed decreased toxicity compared to that of piplartine. Alterations in the trimethoxybenzene ring of piplartine, following unsaturation of the aliphatic chain and the dihydropiperidinone ring, were shown to be highly sensitive to modification, promoting the loss of biological activity and decreased toxicity. These findings indicate that analogous molecules within the same series do not present the same physicochemical and biological activity.

Supplementary Materials: Supplementary materials can be found at http:/ / www.mdpi.com/1422-0067/19/6/ 1802/s1.

Acknowledgments: This work was partially supported by grants from the Fundação de Amparo à Pesquisa do Estado de São Paulo (FAPESP grant number 2016/22488-3), the authors are grateful to CAPES/FAPEPI for the scholarship granted. ACM is grateful to FAPESP (2014/02282-6). YPM is grateful to CNPq (Grant 302674/2010-1). Financial Support: FCT (Fundação para Ciência e Tecnologia) by grant no. UID/MULTI/04378/2013 POCI/01/0145/FEDER/007728, Fapesp (2014/50316-7). The work at UCIBIO/Requimte was supported by the Fundação para a Ciência e a Tecnologia (FCT) with financial support from FCT/MEC through national funds and co-financed by FEDER, under the Partnership Agreement PT2020. Alexandra Plácido is grateful to FCT by her grant SFRH/BD/97995/2013, financed by POPH-QREN-Tipologia 4.1-Formação Avançada, subsidized by Fundo Social Europeu and Ministério da Ciência, Tecnologia e Ensino Superior.

Author Contributions: Conceived and designed the experiments: Yuri Dias Macedo Campelo, Andreanne G. Vasconcelos, Alexandra Plácido, Lydia Fumiko Yamaguchi Yvonne P. Mascarenhas, José Roberto S. A. Leite; Performed the experiments: Yuri Dias Macedo Campelo, Alicia Ombredane, Andreanne G. Vasconcelos, Lucas F. F. Albuquerque, Daniel C. Moreira, Alexandra Plácido, Lydia Fumiko Yamaguchi, Ana Carolina Mafud, Tatiana K. S. Borges, Massuo J. Kato, Josué de Moraes, Jefferson A. Rocha, Harold Hilarion Fokoue, and, Marcos P. Silva; Analyzed the data: Yuri Dias Macedo Campelo, Alicia Ombredane, 
Andreanne G. Vasconcelos, Daniel C. Moreira, Alexandra Plácido, Ana Carolina Mafud, Tatiana K. S. Borges, Graziella A. Joanitti, Daniel E.R. Arcanjo, Massuo J. Kato, Josué de Moraes, José Roberto S. A. Leite. Contributed reagents/materials/analysis tools: Yvonne P. Mascarenhas, Cristina Delerue-Matos, Tatiana K. S. Borges, Graziella A. Joanitti, Massuo J. Kato, Selma S. Kucklhaus, Josué de Moraes, José Roberto S. A. Leite. Wrote the paper: Yuri Dias Macedo Campelo, Alicia Ombredane, Andreanne G. Vasconcelos, Daniel C. Moreira, Alexandra Plácido, Graziella A. Joanitti, Daniel D. R. Arcanjo, Massuo J. Kato, Josué de Moraes, José Roberto S. A. Leite.

\section{Abbreviations}

$\begin{array}{ll}\text { DMSO } & \text { Dimethyl sulfoxide } \\ \text { THF } & \text { Tetrahydrofuran } \\ \text { DCC } & \text { Dicyclohexylcarbodiimide }\end{array}$

\section{References}

1. World Health Organization. Schistosomiasis; WHO: Geneva, Switzerland, 2016; Available online: http: / / who.int/mediacentre/factsheets/fs115/en/ (accessed on 20 November 2017).

2. GBD 2016 Causes of Death Collaborators. Global, regional, and national age-sex specific mortality for 264 causes of death, 1980-2016: A systematic analysis for the Global Burden of Disease study 2016. Lancet 2017, 390, 1151-1210. [CrossRef]

3. GBD 2015 DALYs and HALE Collaborators. Global, regional, and national disability-adjusted life-years (DALYs) for 315 diseases and injuries and healthy life expectancy (HALE), 1990-2015: A systematic analysis for the Global Burden of Disease Study 2015. Lancet 2016, 388, 1603-1658. [CrossRef]

4. Colley, D.G.; Bustinduy, A.L.; Secor, W.E.; King, C.H. Human schistosomiasis. Lancet 2014, 383, $2253-2264$. [CrossRef]

5. Cioli, D.; Pica-Mattoccia, L.; Basso, A.; Guidi, A. Schistosomiasis Control: Praziquantel forever? Mol. Biochem. Parasitol. 2014, 195, 23-29. [CrossRef] [PubMed]

6. Lago, E.M.; Xavier, R.P.; Teixeira, T.R.; Silva, L.M.; da Silva Filho, A.A.; de Moraes, J. Antischistosomal agents: State of art and perspectives. Future Med. Chem. 2018, 10, 89-120. [CrossRef] [PubMed]

7. De Almeida, L.M.; de Carvalho, L.S.; Gazolla, M.C.; Silva Pinto, P.L.; da Silva, M.P.; de Moraes, J.; Da Silva Filho, A.A. Flavonoids and sesquiterpene lactones from Artemisia absinthium and Tanacetum parthenium against Schistosoma mansoni worms. Evid Based Complement Alternat Med. 2016, 2016, 9521349. [CrossRef] [PubMed]

8. De Moraes, J.; Almeida, A.A.; Brito, M.R.; Marques, T.H.; Lima, T.C.; Sousa, D.P.; Nakano, E.; Mendonça, R.Z.; Freitas, R.M. Anthelmintic activity of the natural compound (+)-limonene epoxide against Schistosoma mansoni. Planta Med. 2013, 79, 253-258. [CrossRef] [PubMed]

9. Silva, M.P.; Oliveira, G.L.; de Carvalho, R.B.; de Sousa, D.P.; Freitas, R.M.; Pinto, P.L.; de Moraes, J. Antischistosomal activity of the terpene nerolidol. Molecules 2014, 19, 3793-3803. [CrossRef] [PubMed]

10. Silva, A.P.; Silva, M.P.; Oliveira, C.G.; Monteiro, D.C.; Pinto, P.L.; Mendonça, R.Z.; Costa Júnior, J.S.; Freitas, R.M.; de Moraes, J. Garcinielliptone FC: Antiparasitic activity without cytotoxicity to mammalian cells. Toxicol. In Vitro 2015, 29, 681-687. [CrossRef] [PubMed]

11. De Castro, C.C.; Costa, P.S.; Laktin, G.T.; de Carvalho, P.H.; Geraldo, R.B.; de Moraes, J.; Pinto, P.L.; Couri, M.R.; Pinto Pde, F.; Da Silva Filho, A.A. Cardamonin, a schistosomicidal chalcone from Piper aduncum L. (Piperaceae) that inhibits Schistosoma mansoni ATP diphosphohydrolase. Phytomedicine 2015, 22, 921-928. [CrossRef] [PubMed]

12. De Moraes, J. Natural products with antischistosomal activity. Future Med. Chem. 2015, 7, 1-20. [CrossRef] [PubMed]

13. Parmar, V.S.; Jain, S.C.; Bisht, K.S.; Jain, R.; Taneja, P.; Jha, A.; Tyagi, O.M.; Prasad, A.K.; Wengel, J.; Olsen, C.E.; et al. Phytochemistry of the genus Piper. Phytochemistry 1997, 46, 597-673. [CrossRef]

14. Bezerra, D.P.; Pessoa, C.; de Moraes, M.O.; Saker-Neto, N.; Silveira, E.R.; Costa Lotufo, L.V. Overview of the therapeutic potential of piplartine (Piperlongumine). Eur. J. Pharm. Sci. 2013, 48, 453-463. [CrossRef] [PubMed] 
15. De Moraes, J.; Nascimento, C.; Lopes, P.O.; Nakano, E.; Yamaguchi, L.F.; Kato, M.J.; Kawano, T. Schistosoma mansoni: In vitro schistosomicidal activity of piplartine. Exp. Parasitol. 2011, 127, 357-364. [CrossRef] [PubMed]

16. Moraes, J.; Nascimento, C.; Yamaguchi, L.F.; Kato, M.J.; Nakano, E. Schistosoma mansoni: In vitro schistosomicidal activity and tegumental alterations induced by piplartine on schistosomula. Exp. Parasitol. 2012, 132, 222-227. [CrossRef] [PubMed]

17. Campelo, Y.D.M.; Mafud, A.C.; Véras, L.M.C.; Guimarães, M.A.; Yamaguchi, L.F.; Lima, D.F.; Arcanjo, D.D.R.; Kato, M.J.; Mendonça, R.Z.; Pinto, P.L.S.; et al. Synergistic effects of in vitro combinations of piplartine, epiisopiloturine and praziquantel against Schistosoma mansoni. Biomed. Pharmacother. 2017, 88, 488-499. [CrossRef] [PubMed]

18. De Moraes, J.; Keiser, J.; Ingram, K.; Nascimento, C.; Yamaguchi, L.F.; Bittencourt, C.R.; Bemquerer, M.P.; Leite, J.R.; Kato, M.J.; Nakano, E. In vitro synergistic interaction between amide piplartine and antimicrobial peptide dermaseptin against Schistosoma mansoni schistosomula and adult worms. Curr. Med. Chem. 2013, 20, 301-309. [CrossRef] [PubMed]

19. Ertl, P.; Rohde, B.; Selzer, P. Fast calculation of molecular polar surface area as a sum of fragment-based contributions and its application to the prediction of drug transport properties. J. Med. Chem. 2000, 43, 3714-3717. [CrossRef] [PubMed]

20. Moraes, J. Antischistosomal natural compounds: Present challenges for new drug screens. In Current Topics in Tropical Medicine; Rodriguez-Morales, A.J., Ed.; InTech: Rijeka, Croatia, 2012; pp. 333-358.

21. Silva, M.P.; de Oliveira, R.N.; Mengarda, A.C.; Roquini, D.B.; Allegretti, S.M.; Salvadori, M.C.; Teixeira, F.S.; de Sousa, D.P.; Pinto, P.L.S.; da Silva Filho, A.A.; et al. Antiparasitic activity of nerolidol in a mouse model of schistosomiasis. Int. J. Antimicrob. Agents 2017, 50, 467-472. [CrossRef] [PubMed]

22. Mafud, A.C.; Ferreira, L.G.; Mascarenhas, Y.P.; Andricopulo, A.D.; de Moraes, J. Discovery of novel antischistosomal agents by molecular modeling approaches. Trends Parasitol. 2016, 32, 874-886. [CrossRef] [PubMed]

23. De Moraes, J.; Dario, B.S.; Couto, R.A.; Pinto, P.L.; da Costa Ferreira, A.M. Antischistosomal activity of oxindolimine-metal complexes. Antimicrob. Agents Chemother. 2015, 59, 6648-6652. [CrossRef] [PubMed]

24. Shen, J.; Cheng, F.; Xu, Y.; Li, W.; Tang, Y. Estimation of ADME Properties with Substructure Pattern Recognition. J. Chem. Inf. Model. 2010, 50, 1034-1041. [CrossRef] [PubMed]

25. Uretsky, N.; Robertson, L. Academic Preparation for Modern Drug Discovery. 2004. Available online: http:/ / www.sciencemag.org/careers/2004/03/academic-preparation-modern-drug-discovery (accessed on 20 November 2017).

26. Araújo-Vilges, K.M.; Oliveira, S.V.; Couto, S.C.P.; Fokoue, H.H.; Romero, G.A.S.; Kato, M.J.; Romeiro, L.A.S.; Leite, J.R.S.A.; Kuckelhaus, S.A.S. Effect of piplartine and cinnamides on Leishmania amazonensis, Plasmodium falciparum and on peritoneal cells of Swiss mice. Pharm. Biol. 2017, 55, 1601-1607. [CrossRef] [PubMed]

27. Jain, M.V.; Paczulla, A.M.; Klonisch, T.; Dimgba, F.N.; Rao, S.B.; Roberg, K.; Schweizer, F.; Lengerke, C.; Davoodpour, P.; Palicharla, V.R.; et al. Interconnections between apoptotic, autophagic and necrotic pathways: Implications for cancer therapy development. J. Cell. Mol. Med. 2013, 17, 12-29. [CrossRef] [PubMed]

28. Atale, N.; Gupta, S.; Yadav, U.C.; Rani, V. Cell-death assessment by fluorescent and nonfluorescent cytosolicand nuclear staining techniques. J. Microsc. 2014, 255, 7-19. [CrossRef] [PubMed]

29. Mukhopadhyay, S.; Panda, P.K.; Sinha, N.; Das, D.N.; Bhutia, S.K. Autophagy and apoptosis: Where do they meet? Apoptosis 2014, 19, 555-566. [CrossRef] [PubMed]

30. Dive, C.; Gregory, C.D.; Philips, D.J.; Evans, D.L.; Milner, A.E.; Wylle, A.H. Analysis and discrimination of necrosis and apoptosis (programmed cell death) by multiparameter flow cytometry. Biochem. Biophys. Acta 1992, 1133, 275-285. [CrossRef]

31. Bezerra, D.P.; de Castro, F.O.; Alves, A.P.; Pessoa, C.; de Moraes, M.O.; Silveira, E.R.; Lima, M.A.; Elmiro, F.J.; de Alencar, N.M.; Mesquita, R.O.; et al. In vitro and in vivo antitumor effect of 5-FU combined with piplartine and piperine. J. Appl. Toxicol. 2008, 28, 156-163. [CrossRef] [PubMed]

32. Ponte-Sucre, A.; Bruhn, H.; Schirmeister, T.; Cecil, A.; Albert, C.R.; Buechold, C.; Tischer, M.; Schlesinger, S.; Goebel, T.; Fuß, A.; et al. Piperamides and their derivatives as potential anti-trypanosomal agents. Med. Chem. Res. 2015, 18, 703-711. [CrossRef] 
33. Adams, D.J.; Dai, M.; Pellegrino, G.; Wagner, B.K.; Stern, A.M.; Shamji, A.F.; Schreiber, S.L. Synthesis, cellular evaluation, and mechanism of action of piperlongumine analogs. Proc. Natl. Acad. Sci. USA 2012, 109, 15115-15120. [CrossRef] [PubMed]

34. Marques, J.V.; de Oliveira, A.; Raggi, L.; Young, M.C.; Kato, M.J. Antifungal activity of natural and synthetic amides from Piper species. J. Braz. Chem. Soc. 2010, 21, 1807-1813. [CrossRef]

35. Frisch, M.J.; Trucks, G.W.; Schlegel, H.B.; Scuseria, G.E.; Robb, M.A.; Cheeseman, J.R.; Scalmani, G.; Barone, V.; Mennucci, B.; Petersson, G.A.; et al. Gaussian 09, Revision A.1; Gaussian, Inc.: Wallingford, CT, USA, 2009; Available online: www.gaussian.com (accessed on 22 June 2017).

36. Lee, C.; Yang, W.; Parr, R.G. Development of the colle-salvetti correlation-energy formula into a functional of the electron-density. Phys. Rev. B 1988, 37. [CrossRef]

37. Hohenberg, P.; Kohn, W. Inhomogeneous electron gas. Phys. Rev. 1964, 136. [CrossRef]

38. Pedretti, A.; Villa, L.; Vistoli, G. VEGA-An open platform to develop chemo-bio-informatics applications, using plug-in architecture and script programming. J. Comput. Aided Mol. Des. 2004, 18, 167-173. [CrossRef] [PubMed]

39. Pires, D.E.V.; Blundell, T.L.; Ascher, D.B. pkCSM: Predicting small-molecule pharmacokinetic and toxicity properties using graph-based signatures. J. Med. Chem. 2015, 58, 4066-4072. [CrossRef] [PubMed]

40. Pires, D.E.V.; Blundell, T.L.; Ascher, D.B. Theory - How Tointerpret pkCSM Results; University of Cambridge: Cambridge, UK, 2015; Available online: http://bleoberis.bioc.cam.ac.uk/pkcsm/theory (accessed on 20 November 2017).

41. Śliwka, L.; Wiktorska, K.; Suchocki, P.; Milczarek, M.; Mielczarek, S.; Lubelska, K. The Comparison of MTT and CVS Assays for the Assessment of Anticancer Agent Interactions. PLoS ONE 2016, 11, e0155772. [CrossRef] [PubMed]

42. Keiser, J.; Ingram, K.; Vargas, M.; Chollet, J.; Wang, X.; Dong, Y.; Vennerstrom, J.L. In vivo activity of aryl ozonides against Schistosoma species. Antimicrob. Agents Chemother. 2012, 56, 1090-1092. [CrossRef] [PubMed]

43. De Moraes, J.; de Oliveira, R.N.; Costa, J.P.; Junior, A.L.; de Sousa, D.P.; Freitas, R.M.; Allegretti, S.M.; Pinto, P.L.S. Phytol, a diterpene alcohol from chlorophyll, as a drug against neglected tropical disease Schistosomiasis mansoni. PLoS Negl. Trop. Dis. 2014, 8, e2617. [CrossRef] [PubMed]

44. Mafud, A.C.; Silva, M.P.; Monteiro, D.C.; Oliveira, M.F.; Resende, J.G.; Coelho, M.L.; de Sousa, D.P.; Mendonça, R.Z.; Pinto, P.L.; Freitas, R.M.; et al. Structural parameters, molecular properties, and biological evaluation of some terpenes targeting Schistosoma mansoni parasite. Chem. Biol. Interact. 2016, 244, 129-139. [CrossRef] [PubMed]

45. De Brito, M.R.M.; Peláez, W.J.; Faillace, M.S.; Militão, G.C.G.; Almeida, J.R.G.S.; Argüello, G.A.; Szakonyi, Z.; Fülöp, F.; Salvadori, M.C.; Teixeira, F.S.; et al. Cyclohexene-fused 1,3-oxazines with selective antibacterial and antiparasitic action and low cytotoxic effects. Toxicol. In Vitro 2017, 44, 273-279. [CrossRef] [PubMed]

46. Rocha, J.A.; Andrade, I.M.; Véras, L.M.; Quelemes, P.V.; Lima, D.F.; Soares, M.J.; Pinto, P.L.; Mayo, S.J.; Ivanova, G.; Rangel, M.; et al. Anthelmintic, antibacterial and cytotoxicity activity of imidazole alkaloids from Pilocarpus microphyllus leaves. Phytother. Res. 2017, 31, 624-630. [CrossRef] [PubMed]

47. Dias, M.M.; Zuza, O.; Riani, L.R.; de Faria Pinto, P.; Pinto, P.L.S.; Silva, M.P.; de Moraes, J.; Ataíde, A.C.Z.; de Oliveira Silva, F.; Cecílio, A.B.; et al. In vitro schistosomicidal and antiviral activities of Arctium lappa L. (Asteraceae) against Schistosoma mansoni and Herpes simplex virus-1. Biomed. Pharmacother. 2017, 94, 489-498. [CrossRef] [PubMed]

(C) 2018 by the authors. Licensee MDPI, Basel, Switzerland. This article is an open access article distributed under the terms and conditions of the Creative Commons Attribution (CC BY) license (http:/ / creativecommons.org/licenses/by/4.0/). 